\title{
New Principles of Football Security in Europe
}

\author{
Karina Zalcmane \\ Rìga Stradiñš University, Faculty of Law, Latvia \\ karina.zalcmane@gmail.com
}

\begin{abstract}
On July 3, 2016, the Stade de France stadium in Paris hosted a ceremony of signing the Council of Europe Convention on an Integrated Safety, Security and Service Approach at Football Matches and Other Sports Events (hereinafter referred to as the Convention) (Sport Conventions, 2016). The provisions of the new Convention are aimed at the overall integration of approaches to security issues during the sporting events (Details of Treaty No. 218, 2016).

In order to understand why the European Convention of 1985 is no more relevant, the article offers analysis of the new Convention and its controversial moments.

One of the main objectives of the Convention is to ensure safety, security and favourable atmosphere at football matches and other sports events; for this purpose, the signatories should adopt a single balanced multilateral approach in the spirit of effective local, national and international partnership and cooperation (Details of Treaty No. 218, 2016).

The members shall ensure regular improvement of law enforcement strategies taking into account national and international experience; in case any offense is committed abroad, the members shall cooperate so that the corresponding sanctions were applied to the offender in the country of the offense or in the country of the offender's residence or citizenship.

However, not all countries without hesitation sign and subsequently ratify the Convention. For example, one of the problems is the creation of a National Football Information Point (NFIP) and its integration into the law enforcement system. For many European countries, the NFIP is an innovation; therefore, its establishment shall bring multifarious questions.
\end{abstract}

Keywords: ETS No. 120, football fans, sports Law, violence. 


\section{Introduction}

Though many international efforts to ensure safety during sports events were taken in past decades, football fan violence is still a serious problem. Regrettably, the European Football Championship in France will be remembered for rather the clashes of the police and hooligan fans than showy games.

On July 3, 2016, the Stade de France stadium in Paris hosted a ceremony of signing the Council of Europe Convention on an Integrated Safety, Security and Service Approach at Football Matches and Other Sports Events (hereinafter referred to as the Convention), where the heads of Council of Europe, UEFA and the French Government, as well as a number of Ministers of the EU countries were present (Sport Conventions, 2016). Despite the title of the Convention stating "Football" (which is understandable since football fans have been mostly mentioned in incidents reports), the Council of Europe emphasises that the treaty is equally effective towards other competitive sports requiring special organisation.

The Convention is open for signature by the Council of Europe (hereinafter referred to as the CE) and the European Cultural Convention member states, as well as by nonmember states that have acceded to the European Convention on Spectator Violence and Misbehaviour at Sports Events and in particular at Football Matches [European Treaty Series, No. 120, Strasbourg, August 19, 1985] (Details of Treaty No. 218, 2016).

The signing ceremony was attended by Thorbjørn Jagland, the CE Secretary General, Michael L. van Prague, the Union of European Football Associations (UEFA) Stadiums and Security Chairman, and other officials. The first signatories to the Convention were France, Bulgaria, Georgia, Greece, Lithuania, Monaco, Montenegro, Netherlands, Portugal, Macedonia, Switzerland, Moldova, Russia and Ukraine (Sport Conventions, 2016).

The Convention enters into force immediately once ratified by at least three European states (Details of Treaty No. 218, 2016), which was expected right in 2016, as almost all states had expressed their will to accede to the Convention before.

So far, the Convention has been signed by representatives of 29 European countries (as it is on January 20, 2018) and ratified by six (Details of Treaty No. 218, 2016). The Convention entered into force on November 1, 2017.

\section{Aim}

The aim of the study was to understand why the European Convention of 1985 is no more relevant and why only six signatories from 29 have ratified it.

\section{Hypothesis}

Despite the signing and ratification of the Council of Europe Convention on an Integrated Safety, Security and Service Approach at Football Matches and Other Sports Events will not result in heavy sports reforms in many countries; some participants are rather hesitant to ratify it, since its implementation will bring some important changes in the national legislation and football infrastructure. 


\section{Methods}

In order to confirm the hypothesis and to conduct a conclusion, the following methods of theoretical research were used: method of description, in order to describe the state of affairs as currently existent; comparative method, in order to understand why the European Convention of 1985 is no more relevant; induction and deduction.

\section{Results}

According to UEFA, about $46 \%$ of all matches are followed by incidents, a quarter of them being rated serious or critical. Between 2013 and 2015, the number of disciplinary cases against the state or its team has increased by $64 \%$ (Bengtsson, 2016).

The new treaty supersedes the European Convention on Spectator Violence and Misbehaviour at Sports Events and in particular at Football Matches developed in 1985 after the Heysel Stadium Disaster in Brussels (Details of Treaty No. 218, 2016). Then, during the European Cup, a final match between Juventus (Italy) and Liverpool (England), a conflict of fans resulted in a collapsed stand causing 39 people dead and hundreds wounded (The Heysel disaster, 2000).

The Convention provides the participating States with an arsenal of practices to ensure safety of the spectators at sporting events. It defines the list of actions to stop and prevent violence.

It is designed to ensure security during sports events, as well as consolidate international police cooperation and promote interaction of law enforcement agencies, local authorities, football clubs and fans (Details of Treaty No. 218, 2016). One of the treaty's aims is to organise interaction of interested parties to ensure safety during matches.

This is already a common practice in a number of countries. The most severe prohibitions against fan violence are in the UK; there several laws on spectator behaviour at football stadiums were passed at once (Anderson \& Banerjee, 2015). If the UK team plays abroad, the police, for example, may confiscate the blacklisted fans' passports for a certain time period (Siekmann, et al., 2004). Since the measure is temporary, nobody's right to freedom of movement is violated; as for the period of such confiscation, it is at the discretion of the state. The Convention stresses, however, that the imposed sanctions shall be in strict accordance with national judicial or executive legislation.

Besides, the UK football clubs and other sports organisations use a well-developed membership system. These organisations provide active assistance in identifying hooligans. For example, a fan violating the stadium code of conduct may be stripped of his membership.

Laws to ensure spectators' safety are also adopted in some German states. For causing damage at the stadium, the offender's club may decide to ban him from attending football matches for a period of up to five years, and the non-compliant offender may be sentenced for a term of up to six months (Noli, 2016). 
German police may give fans $B$ and $C$ categories, such a warning against their unauthorised departure, in order to prevent hooligans from leaving the country for international football matches (Noli, 2016). These fans may also be put under official control.

Another preventive measure in Germany, likewise in England, is confiscating a fan's passport for a certain time period, thus making them unable to buy a train or plane ticket (Hyland, 2000). Fans may also be invited to an interview at the police station. Ignoring the invitation may result in a fine of up to $€ 500$ or in an administrative arrest (Noli, 2016). The information on persons under such a restriction goes to the border services.

Once the law was enacted, the German fans raised numerous complaints for violation of their constitutional rights to watch football matches at the stadiums; all such cases, though, had negative court resolutions (Noli, 2016).

Restrictions on attending football matches (personal ID card access) are also applied in Italy and Poland. In Italy, an attendance ban is the decision of the Police Commissar (Caruso \& Domizio, 2013); a Polish fan may be banned by his football club (Gonda, 2013).

Russia adopted the law regulating behaviour at sporting events in July 2013 (enacted as of January 20, 2014) (“Закон о болельщиках” вступает в силу в понедельник (Eng. "Law on Fans" comes into force on Monday), 2014); rules of conduct during official sports events were adopted in December 2013 (Об утверждении Правик повеАения зрителей при проведении официальных спортивных соревнований (Eng. Approval of the rules of conduct of viewers in the event of official sports competitions), 2013).

According to the current legislation, the penalty for violation of the above rules is a fine of 10,000 roubles (approx. $€ 155$ ) and up to 160 hours of compulsory community service with a possible 6-36 months ban on attending matches ("Закон о болемьщиках" вступает в силу в понедельник (Eng. "Law on Fans" comes into force on Monday), 2014]. Moreover, a violator fan can be arrested for a period of up to 15 days and get 6-84 months attendance ban (“Закон о болельщиках” вступает в силу в понедельник (Eng. "Law on Fans" comes into force on Monday), 2014].

So far, Latvia has not officially acceded to the latest Council of Europe Convention on an Integrated Safety, Security and Service Approach at Football Matches and Other Sports Events.

Like many CE countries, Latvia has its experience in organising and holding international competitions. However, the visitors thereto cannot always feel comfortable and safe. Nevertheless, it is because of rather radically-minded fans from other countries than the behaviour of local fans.

For Latvia, signing and subsequent ratification of the Convention would mean a significant change of both legal system and the whole sports infrastructure. 


\section{Discussion}

Despite the signing and ratification of the Convention will not result in heavy sports reforms in many countries, some participants may still face the following challenges (Council of Europe Convention on an Integrated Safety, Security and Service Approach at Football Matches and Other Sports Events, 2016):

- The Convention obliges its participants to adopt new regulations and certification systems dealing with stadium licensing and security, as well as to ensure a stadium design, infrastructure and human flow management compliance with international standards. Also, the treaty concerns the improvement of sanitation facilities, access ways for children, senior people and people with disabilities, regulation of ticket sales, alcohol consumption and use of pyrotechnics, separation of competing fans, counter-terrorism measures and measures against black marketing. Given the potential conflict of interest (for example, where stadiums belong to local authorities), the Convention points out at the need for a clear separation of concerns as to managing municipal property at stadiums and stadium licensing. Thus, many countries ratifying the Convention will need to rebuild their football infrastructure.

- Many countries will have to amend their legislation and provide for a number of preventive and punitive measures for violence and hooliganism, restrictions on leaving the country for football events among them. The Convention also considers imposing sanctions against the country where the crime was committed or the country of an offender's residence or citizenship, as well as banning stadiums from holding competitions. At the same time, it is still a national legislation prerogative to determine who to punish, why and to what extent. It is worth noting that the widespread punishment, an empty stands game, hardly favours sports or its values.

- Once the convention is ratified by ten countries, a committee on safety and security at sporting events will be established to start implementing its regulations. The committee will monitor the execution of the Convention and give, where necessary, its recommendations on changing legislation, law enforcement practices or policies concerning sports. A signing country is thereby lumbered with a supervisor and a liability to make changes to its relevant laws, which may not always be useful for the national legislator, the scientific society and society as a whole.

- One of the measures to be implemented is a personalised card or fan passport (fan ID). The card will be tested during World Cup 2018, the championship matches to be held at 12 stadiums in 11 Russian cities. Only fans having the card will be allowed to enter the host country.

- Local authorities and special organisations are recommended to boost their cooperation with organised fans, especially football fans. Every club should 
have people responsible for cooperation with their fans and communication with the police. Fan communities are expected to establish strict rules of conduct and monitor their implementation. Law enforcement agencies, in their turn, should allocate officers able to build a constructive dialogue with fans and establish contacts with their European counterparts, particularly, with the officers of the UEFA Pan-European Safety Centre. Besides, some countries are advised to consider introducing the institute of the so-called spotters, which has proven successful in several European countries. Spotters are police officers who understand fan culture and rules of conduct and help a fan to build adequate relations with law enforcement bodies (O'Neill, 2005). A spotter's main task is to prevent violations and conflicts, as well as minimise force interaction of a fan and an officer (O’Neill, 2005).

- One of the main problems is the creation of a National Football Information Point (NFIP) and its integration into the law enforcement system.

The NFIP should become a single contact point to exchange, under international cooperation, the latest strategic and tactical information on football matches and personal data in accordance with national and international regulations, as well as to provide, coordinate or organise the international law enforcement cooperation during global football matches.

Furthermore, given the content of the Convention, the NFIP shall be a national source of information on police experience during football matches; the NFIP shall also develop fan environment and study the associated risks to ensure safety and security.

For many European countries, the NFIP is an innovation; therefore, its establishment shall bring multitude of questions.

\section{Conclusion}

Despite most experts in sports law evaluate the EC Europe Convention on an Integrated Safety, Security and Service Approach at Football Matches and Other Sports Events positively, a signatory may face the following challenges upon its ratification:

- Partial or complete change of football infrastructure.

- Numerous changes in criminal and / or administrative laws.

- Cooperation with a supervisory body.

- Implementation of special preventive tools (personalised card or a fan ID) followed by training.

- Establishment of a National Football Information Point (NFIP) and its integration into the existing law enforcement system.

And yet still, any international treaty or new sports security laws will work only when the relevant legal conditions and implementation mechanisms are established at the national level. So far, the Convention has only been ratified by six of 29 signatories. When the document comes into its full effect remains an unanswered question. 


\section{Jaunie futbola drošības principi Eiropā}

\section{Kopsavilkums}

2016. gada 3. jūlijā Francijā, Stade de France stadionā, tika rīkota parakstīšanas ceremonija Eiropas Padomes Konvencijai par integrētu pieeju drošǐbai, drošumam un pakalpojumiem futbola spēlēs un citos sporta pasākumos (turpmāk tekstā - Konvencija, Sport Conventions, 2016) . Jaunās Konvencijas noteikumi ir vērsti uz vispārīgu pieeju drošības jautājumiem sporta pasākumu laikā uz šo normu integrēšanu (Details of Treaty No. 218, 2016).

Lai saprastu, kāpēc 1985. gada Eiropas Konvencija nav vairs saistoša, rakstā piedāvāta jaunās Konvencijas un ar to saistīto pretrunīgo jautājumu analīze.

Viens no Konvencijas galvenajiem mērķiem ir garantēt drošību, apsardzi un labvēlīgu gaisotni futbola spẹlu un citu sporta pasākumu laikā; šajā nolūkā Konvencijas parakstītājiem būtu jāpieņem vienota un līdzsvarota daudzpusēja pieeja, pamatojoties uz efektīvu vietējo, valsts un starptautiska mēroga partnerību un sadarbību (Details of Treaty No. 218, 2016).

Dalībniekiem jānodrošina regulāra tiesību aizsardzības stratēǵiju pilnveidošana, ņemot vērā valsts un starptautisko pieredzi; ja likumpārkāpums ir izdarīts ārvalstī, dalībniekiem ir jāsadarbojas, lai atbilstošas sankcijas tiktu piemērotas pret likumpārkāpēju valstī, kurā ir izdarīts likumpārkāpums, vai likumpārkāpēja dzīvesvietas vai pilsonības valstī.

Tomēr ne visas valstis steidz parakstìt un vēlāk ratificēt šo Konvenciju. Piemēram, viena no problēmām ir Nacionālā futbola informācijas centra (NFIC) izveidošana un tā integrācija tiesībaizsardzības sistēmā.

Daudzām Eiropas valstīm NFIC ir jauninājums, tāpēc tā izveide raisa daudz dažādu jautājumu.

Atslēgvārdi: ETS Nr. 120, futbola līdzjutēji, sporta tiesības, vardarbība.

\section{References}

1. Anderson, G., Banerjee L. Regulating unruly football fans: the state of English law and proposed improvements. 2015. Law In Sport. Available from https://www.lawinsport.com/blog/item/ regulating-unruly-football-fans-the-state-of-english-law-and-proposed-improvements [accessed on 08.05.2017].

2. Bengtsson, $\mathrm{H}$. Football violence on the rise again: UEFA disciplinary actions up $64 \%$ in two years. 2016. The Guardian. Available from https:/www.theguardian.com/football/datablog/2016/ jun/18/football-violence-on-the-rise-again-uefa-disciplinary-actions-up-64-in-two-years [accessed on 08.05.2017].

3. Caruso R., Domizio M. Hooliganism and demand for football in Italy: Attendance and counterviolence policy evaluation. 2013. Available from http://wp.comunite.it/data/wp_no_101_2013. pdf [accessed on 08.05.2017]. 
4. Council of Europe Convention on an Integrated Safety, Security and Service Approach at Football Matches and Other Sports Events of 3 July, 2016. Available from https://www.coe.int/en/web/ conventions/full-list/-/conventions/rms/0900001680666d0b [accessed on 08.05.2017].

5. Details of Treaty No. 218. 2016. Available from https://www.coe.int/en/web/conventions/fulllist/-/conventions/treaty/218 [accessed on 20.01.2018].

6. Gonda, M. Supporters' movement "Against modern football” and sport mega events: European and Polish contexts. Przeglad Socjologiczny, 2013; 62(3): 85-106.

7. Hyland, J. New measures against football hooligans undermine civil liberties in Britain. 2000. World Socialist Web Site. Available from https://www.wsws.org/en/articles/2000/08/act-a29. html [accessed on 08.05.2017].

8. Neill, M. Policing Football. London, UK: Palgrave Macmillan, 2005.

9. Noli, M. Legal Measures and Strategies Against Violence at Football Events in Germany. In: Tsoukala, A., Pearson, G., Coenen, P. (Ed.). Legal Responses to Football Hooliganism in Europe. The Hague, The Netherlands: T. M. C. Asser Press, 2016. - pp. 53-73.

10. Siekmann, R., Gardiner, S., Soek, J., Olfer, M., Mojet, H. Football hooliganism with an EU dimension: towards an international legal framework. 2004. Available from http://www.asser. nl/media/2169/cms_sports_49_1_report-hooliganism.pdf [accessed on 08.05.2017].

11. Sport Conventions. Available from http://www.coe.int/t/DG4/sport/News/NewsTRV_14signatories_NewConvention_en.asp [accessed on 26.12.2016].

12. The Heysel disaster. $B B C$. Available from http://news.bbc.co.uk/2/hi/uk_news/768380.stm [accessed on 08.05.2017].

13. “Закон о болельщиках” вступает в сику в понедельник (Eng. "Law on Fans” comes into force on Monday). 2014. Российская Газета. Available from https://rg.ru/2014/01/20/zakon-anons. html [accessed on 08.05.2017].

14. Об утверждении Правим поведения зрителей при проведении официамьных спортивных соревнований (Eng. Approval of the rules of conduct of viewers in the event of official sports competitions). 2013. Available from http://government.ru/docs/8976/ [accessed on 08.05.2017]. 